\title{
TABLE OF CONTENTS VOLUME 42
}

EDITORIAL

Gass Susan and Plonsky Luke. Introducing the SSLA Methods Forum

The Albert Valdman Award

\section{RESEARCH ARTICLES}

BRYFONSKI, LARA, AND MA, XUE. Effects of Implicit Versus Explicit Corrective Feedback on Mandarin Tone Acquisition in a SCMC Learning Environment

CHAN, RICKY KW, AND LEUNG, JANNY HC. Why are Lexical Tones Difficult to Learn? Insights from the Incidental Learning of Tone-Segment Connections

DE CAT, CÉCILE. Predicting Language Proficiency in Bilingual Children

DEYGERS, BART. Elicited Imitation: A Test for All Learners?: Examining the EI Performance of Learners with Diverging Educational Backgrounds

DURAN-KARAOZ, ZEYNEP, AND TAVAKOLI, PARVANEH Predicting L2 Fluency from L1 Fluency Behavior: The Case of L1 Turkish and L2 English Speakers

ELGORT, IRINA, BELIAEVA, NATALIA, AND BOERS, FRANK. Contextual Word Learning in the First and Second Language: Definition Placement and Inference Error Effects on Declarative and Nondeclarative Knowledge 
FENG, YANXUE, AND WEBB, STUART. Learning Vocabulary through Reading, Listening, and Viewing Which Mode of Input is Most Effective?

GARCÍA-AMAYA, LORENZO, AND LANG, SEAN. Filled Pauses are Susceptible to Cross-Language Phonetic Influence: Evidence from Afrikaans-Spanish Bilinguals

HUI, BRONSON. Processing Variability in Intentional and Incidental Word Learning: An Extension of Solovyeva and Dekeyser (2018)

KANWIT, MATTHEW, AND GEESLIN, KIMBERLY L. Sociolinguistic Competence and Interpreting Variable Structures in a Second Language: A Study of the Copula Contrast in Native and Second-Language Spanish

$775-799$

KIM, HYUNWOO, SHIN, GYU-HO, AND HWANG, HAERIM. Integration of Verbal and Constructional Information in the Second Language Processing of English Dative Constructions

KIM, JEONG-EUN, CHO, YEJIN, CHO, YOUNGSUN, HONG, YEONJUNG, KIM, SEOHYUN, AND NAM, HOSUNG.

The Effects of L1-L2 Phonological Mappings on L2 Phonological Sensitivity: Evidence from Self-Paced Listening

LEE, EUN-KYOUNG ROSA. Age of Onset, Type of Exposure, and Ultimate Attainment of L2 Morpho-Syntactic Sensitivity

LEE, MINJIN AND RÉVÉSZ, ANDREA. Promoting Grammatical Development through Captions and Textual Enhancement in Multimodal Input-Based Tasks

LI, PENG, BAILLS, FLORENCE, AND PRIETO, PILAR. Observing and Producing Durational Hand Gestures Facilitates the Pronunciation of Novel Vowel-Length Contrasts

MAIE, RYO, AND DEKEYSER, ROBERT M. Conflicting Evidence of Explicit and Implicit Knowledge from Objective and Subjective Measures

MARECKA, MARTA, WREMBEL, MAGDALENA, OTWINOWSKA, AGNIESZKA, SZEWCZYK, JAKUB, BANASIK-JEMIELNIAK, NATALIA, AND WODNIECKA, ZOFIA. Bilingual Children's Phonology Shows Evidence of Transfer, but not Deceleration in Their L1

MARECKA, MARTA, FOSKER, TIM, SZEWCZYK, JAKUB, KAŁAMAŁA, PATRYCJA, AND WODNIECKA, ZOFIA. An Ear for Language: Sensitivity to Fast Amplitude Rise Times Predicts Novel Vocabulary Learning

MILLER, ZACHARY F., AND GODFROID, ALINE. Emotions in Incidental Language Learning: An Individual Differences Approach 
NOROUZIAN, REZA. Sample Size Planning in Quantitative

L2 Research: A Pragmatic Approach

$849-870$

PELLICER-SÁNCHEZ, ANA, TRAGANT, ELSA, CONKLIN,

KATHY, RODGERS, MICHAEL, SERRANO, RAQUEL AND

LLANES, ÀNGELS. Young Learners' Processing of Multimodal

Input and its Impact on Reading Comprehension:

An Eye-Tracking Study

$577-598$

PEREZ, MARIBEL MONTERO. Incidental Vocabulary

Learning through Viewing Video: The Role of Vocabulary

Knowledge and Working Memory

$749-773$

PUIMÈGE, EVA, AND PETERS, ELKE. Learning Formulaic

Sequences through Viewing L2 Television and Factors that

Affect Learning

PUJADAS, GEÒRGIA, AND MUÑOZ, CARMEN. Examining

Adolescent EFL Learners'TV Viewing Comprehension through

Captions and Subtitles

$551-575$

QUESADA, TERESA, AND LOZANO, CRISTÓBAL.

Which Factors Determine the Choice of Referential Expressions in

L2 English Discourse?: New Evidence from the COREFL Corpus

959-986

SHOWALTER, CATHERINE E. Russian Phono-Lexical Acquisition

and Orthographic Input: Nä̈ve Learners, Experienced Learners, and Interventions

$255-277$

SOTO-COROMINAS, ADRIANA, PARADIS, JOHANNE, RUSK, BRIAN V., MARINOVA-TODD, STEFKA, AND ZHANG, XUAN. Oral Language Profiles of English Second Language Learners in Adolescence: Cognitive and Input Factors Influence How They Compare to their Monolingual Peers

SUZUKI, SHUNGO, AND KORMOS, JUDIT. Linguistic Dimensions

of Comprehensibility and Perceived Fluency: An Investigation

of Complexity, Accuracy, and Fluency in Second Language

Argumentative Speech

SUZUKI, YUICHI, AND SUNADA, MIDORI. Dynamic Interplay

Between Practice Type and Practice Schedule in a Second Language:

The Potential and Limits of Skill Transfer and Practice Schedule

$169-197$

VAFAEE, PAYMAN, AND SUZUKI, YUICHI. The Relative

Significance of Syntactic Knowledge and Vocabulary Knowledge in Second Language Listening Ability

WISNIEWSKA, NATALIA, AND MORA, JOAN C. Can Captioned Video Benefit Second Language Pronunciation?

YANAGISAWA, AKIFUMI, WEBB, STUART. AND UCHIHARA,

TAKUMI. How Do Different forms of Glossing Contribute to L2

Vocabulary Learning from Reading? A Meta-Regression Analysis

411-438 
ZHAO, HELEN, HUANG, SHUTING, ZHOU, YACONG, AND WANG, RUIMING. Schematic Diagrams in Second Language Learning of English Prepositions: A Behavioral and Event-Related Potential Study

\section{RESEARCH REPORTS}

FRANCES, CANDICE, DE BRUIN, ANGELA, AND DUÑABEITIA, JON ANDONI. The Influence of Emotional and Foreign Language Context in Content Learning

KANG, OKIM, MORAN, MEGHAN, AHN, HYUNKEE, AND PARK, SOON. Proficiency as a Mediating Variable of Intelligibility for Different Varieties of Accents

KIM, KATHY MINHYE, AND FENN, KIMBERLY M. Sleep-Dependent Consolidation of Second Language Grammar Knowledge: The Role of Awareness

LI, JUNMIN, AND TAFT, MARCUS. The Processing of English Prefixed Words by Chinese-English Bilinguals

LOEWEN, SHAWN, GÖNÜLAL, TALIP, ISBELL, DANIEL R., BALLARD, LAURA, CROWTHER, DUSTIN, LIM, JUNGMIN, MALONEY, JEFFREY AND TIGCHELAAR, MAGDA. How Knowledgeable are Applied Linguistics and SLA Researchers about Basic Statistics? Data from North America and Europe

PETERS, ELKE, AND MUÑOZ, CARMEN. Introduction to the Special Issue Language Learning from Multimodal Input 489-497

SACHS, REBECCA, HAMRICK, PHILLIP, MCCORMICK, TIMOTHY J., AND LEOW, RONALD P. Exploring the Veridicality and Reactivity of Subjective Measures of Awareness: Is a "Guess" Really a Guess?

SCHMIDT, ELAINE, PÉREZ, ANA, CILIBRASI, LUCA, AND TSIMPLI, IANTHI. Prosody Facilitates Memory Recall in L1 but not in L2 in Highly Proficient Listeners

SONG, YOONSANG, DO, YOUNGAH, THOMPSON, ARTHUR L., WAEGEMAEKERS, EILEEN R., AND LEE, JONGBONG. Second Language Users Exhibit Shallow Morphological Processing

ZHANG, RUNHAN, AND YUAN, ZHOU-MIN. Examining the Effects of Explicit Pronunciation Instruction on the Development of L2 Pronunciation 905-918

\section{COMMENTARY}

PEREZ, MARIBEL MONTERO. Multimodal Input in SLA Research 


\section{ADDENDUM/CORRIGENDUM}

FRANCES, CANDICE, DE BRUIN, ANGELA, AND DUÑABEITIA, JON ANDONI. The Influence of Emotional and Foreign Language Context in Content Learning - Addendum 1169-1169

PELLICER-SÁNCHEZ, ANA, TRAGANT, ELSA, CONKLIN, KATHY, RODGERS, MICHAEL, SERRANO, RAQUEL, AND LLANES, ÀNGELS. Young Learners' Processing of Multimodal Input and its Impact on Reading Comprehension: An Eye-Tracking Study - Corrigendum

SUZUKI, SHUNGO, AND KORMOS, JUDIT. Linguistic Dimensions of Comprehensibility and Perceived Fluency: An Investigation of Complexity, Accuracy, and Fluency in Second Language Argumentative Speech - Corrigendum

\section{STATE OF THE SCHOLARSHIP}

BARDOVI-HARLIG, KATHLEEN AND COMAJOAN-COLOMÉ, LLORENÇ. The Aspect Hypothesis and the Acquisition of L2 Past Morphology in the Last 20 Years: A State-Of-TheScholarship Review

RICE, CAITLIN A., AND TOKOWICZ, NATASHA. A Review of Laboratory Studies of Adult Second Language Vocabulary Training

ZHANG, XIAN. A Bibliometric Analysis of Second Language Acquisition Between 1997 and 2018 


\section{STUDIES IN SECOND LANGUAGE ACQUISITION}

\section{Information for Contributors}

For guidelines and requirements regarding manuscript submission, please consult the SSLA website at http://journals.cambridge.org/sla. Click on the Journal Information tab which will lead you to Information for Contributors. Potential authors are advised that all manuscripts are internally reviewed for both content and formatting/style in order to determine their suitability for external evaluation.

Research Article. These manuscripts may be essays or empirical studies, either of which must be motivated by current theoretical issues in second and subsequent language acquisition or heritage language acquisition, including methodological issues in research design and issues related to the context of learning. Maximum length is 11,000 words all-inclusive (i.e., abstract, text, tables, figures, references, notes, and appendices intended for publication must all fall within the 11,000 word limit).

Research Report. These manuscripts are shorter empirical studies motivated by current theoretical issues in second and subsequent language acquisition or heritage language acquisition, including methodological issues in research design. Very often, these are narrowly focused studies or they present part of the results of a larger project in progress. The background and motivation sections are generally shorter than research articles. Maximum length is 6,000 words all-inclusive (i.e., abstract, text, tables, figures, references, notes, and appendices intended for publication must all fall within the 6,000 word limit).

Replication Study. These manuscripts are shorter empirical studies motivated by a previously published study (not necessarily one published in SSLA). The background and motivation sections will necessarily be shorter compared to research articles as the maximum length is 6,000 words all-inclusive (i.e., abstract, text, tables, figures, references, notes, and appendices intended for publication must all fall within the 6,000 word limit).

State-of-the-Scholarship Article. These manuscripts are essays that review the extant research on a particular theme or theoretical issue, offering a summary of findings and making critical observations on the research to date. Manuscripts in this category typically fall within the 11,000-word limit of regular research articles; however, longer manuscripts may be considered on a case-by-case basis.

Critical Commentary. These manuscripts are shorter essays (i.e., non-empirical) motivated by current theory and issues in second and subsequent language acquisition or heritage language acquisition, including methodological issues in research design and issues related to the context of learning. Maximum length is 6,000 words all-inclusive (i.e., abstract, text, tables, figures, references, notes, and appendices intended for publication must all fall within the 6,000 word limit).

Methods Forum. Recognizing the need to discuss and advance SLA research methods, these manuscripts seek to advance methodological understanding, training, and practices in the field. Submissions can be conceptual or empirical; we also encourage articles introducing novel techniques. All research paradigms, epistemologies, ontologies, and theoretical frameworks relevant to SLA are welcome. The target length is up to 11,000 words, although longer manuscripts will be considered with justification.

All manuscripts in all categories are peer reviewed and subject to the same high standards for publication in SSLA. 


\section{Studies in Second Language Acquisition Volume 42 Number 5 December 2020}

\section{RESEARCH ARTICLES}

Elicited Imitation: A Test for All Learners? Examining the EI Performance of Learners with Diverging Educational Backgrounds

Bart Deygers

Which Factors Determine the Choice of Referential Expressions in L2 English Discourse? New Evidence from the COREFL Corpus

Teresa Quesada and Cristóbal Lozano

An Ear for Language: Sensitivity to Fast Amplitude Rise Times Predicts

Novel Vocabulary Learning

Marta Marecka, Tim Fosker, Jakub Szewczyk, Patrycja Kałamała,

and Zofia Wodniecka

Observing and Producing Durational Hand Gestures Facilitates the

Pronunciation of Novel Vowel-Length Contrasts

Peng Li, Florence Baills, and Pilar Prieto

The Effects of L1-L2 Phonological Mappings on L2 Phonological Sensitivity:

Evidence from Self-Paced Listening

Jeong-eun Kim, Yejin Cho, Youngsun Cho, Yeonjung Hong,

Seohyun Kim, and Hosung Nam

Filled Pauses are Susceptible to Cross-Language Phonetic Influence:

Evidence from Afrikaans-Spanish Bilinguals

Lorenzo García-Amaya and Sean Lang

\section{RESEARCH REPORTS}

Sleep-Dependent Consolidation of Second Language Grammar Knowledge:

The Role of Awareness

Kathy MinHye Kim and Kimberly M. Fenn

Second Language Users Exhibit Shallow Morphological Processing

Yoonsang Song, Youngah Do, Arthur L. Thompson,

Eileen R. Waegemaekers, and Jongbong Lee

\section{STATE OF THE SCHOLARSHIP}

The Aspect Hypothesis and the Acquisition of L2 Past Morphology in the Last 20 Years: A State-Of-The-Scholarship Review

Kathleen Bardovi-Harlig and Llorenç Comajoan-Colomé

\section{ADDENDUM}

The Influence of Emotional and Foreign Language Context in

Content Learning - Addendum

Candice Frances, Angela de Bruin, and Jon Andoni Duñabeitia Index 